\title{
Libraries in the system of social-information communications
}

\author{
O. N. Karaschuk
}

V.I. Vernadsky National Library of Ukraine

Corresponding author. E-mail: karaoksana@ukr.net

Paper received 11.11.17; Revised 14.11.17; Accepted for publication 15.11.17.

https://oi.org/10.31174/SEND-HS2017-146V24-13

\begin{abstract}
The article deals with the general tendencies of the development of social information communications and the role of libraries as the basic social and communicative structure that concentrates the communicative culture of society and provides communication processes in society. It has been proved that libraries have solid advantages in competition with other information structures by accessing huge amounts of information in their funds. Have been analyzed the scientific works on the presented topics.

Keywords: social information communications, verbal and non-verbal communication, library resources, library institutions, library communicative potential.
\end{abstract}

The present civilization, having undergone a certain way in its historical development, is a complex system of human communities that, during its evolution, gets more characteristics of a holistic social organism. The internal unity of this organism is ensured by the development of a system of appropriate social communications that is constantly being improved in line with growing social needs, based on the development of the scientific and technological process, stimulated, in turn, by a socially useful work. Today, this process of intensive improvement of the system develops primarily in two main areas: improving the quality and intensity of the circulation of information in existing channels, as well as multiplication, improvement of existing channels in the process of organization of the access to user information, for the maintenance of new social structures created during the social evolution.

The article is devoted to highlighting the process of functioning of the system of social information communications and the place and role of library institutions in it.

This problem has been reflected in the writings of contemporary domestic and foreign researchers, for example: O.S. Onishchenko, V.M. Gorovy, O. Mizin, V.Yu. Vakhnovana, E. Aronson, E. Prataknis, V. Maturana, and others.

The development of the system of general civilizational social communications in the process of global evolution is becoming increasingly important. Accordingly, the growing importance for society is the awareness of the content of social communications, characteristics and potential opportunities, awareness of the process of complication of the social structure of society, which determines the rapid development of diversity in terms of material expression and the content of social communications, which in its totality is an increasingly complex, multilevel system. This system promotes the strengthening of social unity of society, and is an important factor in the development of opportunities for its further development. This process has been obvious and active over the last few decades. At this time, the improvement of the social structure of society is closely linked with the dynamic development of democratic processes, the active development of political structures in most of the countries of the world.

In the process of accelerating the social development of the second half of the twentieth century the saturation of the information, informational support of the transformations, which later became known as the informatization of society, is growing. In this regard, the importance of information communications in the system of mechanisms of social exchanges is increasing and the researchers are paying more and more attention to it. Gradually is forming the view of such communications as a mechanism of communication, the transfer of information from person to person - a specific form of interaction of people in the process of their cognitive-work activities. Communication is a socially conditioned process of transmission and perception of information in conditions of interpersonal and mass communication for various channels through various communication tools. Any communication is carried out in a certain space and time. In the process of communication, information is transmitted using two sign systems - verbal and nonverbal. Verbal is provided for the purposeful verbal transmission of a certain message. Therefore, speech (language) is the most universal means of implementation of communication. Non-verbal communication covers: kinesic (code of gestures and movements), physiognomy (appearance), voice effects (laughs, exclamations, etc.), tactics (the use of touch as communication), etc. The main purpose of communication is the transfer of information, the exchange of experience, certain impressions, emotions [5].

With the development of the technical base of mass media, their influence in society increases and, accordingly to this, the concept of the content of mass communications is intensified as an instrument of cultural interaction in the scale of society, one of the fundamental factors of its development. Due to the circulation of knowledge, values, norms, social meanings in the society, those factors are symbolically covered by the complex structure of social space, available for the perception of mass, normative individual consciousness.

In social information communications, the object is social information - the information that functions in society; means of communication of social information in communications may be any of the known means of communication, including electronic media, as well as technical and other devices that provide the delivery of information on certain media. Forms of information transfer are all developed by the practice of social informing of the genres of electronic information, printed word, language, science, all kinds of arts symbols, folk art, etc. The universal scheme of social information communications includes, in addition to the object being transmitted, two or more subjects, each of which may in turn include an individual, a group of people, and society.

In general, modern ideas about information communications prove that they are based on industrial relations and depend on both their level of development and the 
development of the respective productive forces; the purpose of their functioning is to unite the types of activities necessary for the existence of a society, coordinate its interests of the targeted activities of existing social institutions, individual members of society. In addition, the presence of the necessary internal-social exchange of results of material and spiritual production.

At the same time, the introduction into the public circulation of available information in volumes commensurate with the volume of production of new information is fundamentally important to society, since it should provide an appropriate benchmark, continuity of scientific, moral and the cultural traditions of the development of society, which is very important in the context of the intensification of global processes. The solution of this problem today is impossible without rethinking the role of the library institutions in modern conditions, the introduction of important components of these institutions into the system of modern information communications, which ensure the viability and development of society.

Together with the development of science and scientific knowledge, which, as rightly noted by the researchers, gave rise to "information explosion", its cause was the realization of certain opportunities of modern technological progress. especially with the development of electronic information technology. Under their influence, not only access to available information resources for an increasing number of members of society is constantly expanding, but also opportunities for producing their own new information and introducing it into the system of social communications.

To date, the relative autonomy of social communications management, scientific communications, political, which to some extent, but not completely imposed on the system of mass communication. Moreover, the existence of a well-formed social request for information has become an important factor in the restructuring of library work, especially its information and analytical aspects. This contributes to the active disclosure of funds to users, the efficient use of knowledge accumulated in the process of historical development of humanity, information resources stored in library and other institutions on various, including complex for use in the system of modern communications, carriers.

The growing importance of social communications in the life of modern society has already reached the level where the further evolution of such an instrument of social organization can no longer occur spontaneously, it would require serious public attention, scientific approaches to studying the content of this phenomenon, its features, analysis of existing experience and the development of the necessary predictive landmarks . Naturally, researchers in recent times pay more attention to the study of various aspects of this problem as an independent subject of study [6]. Significant interest in this study is a scientific development in the field of interpersonal communication E. Aronson [1]; for the analysis of socialcultural communications and the various forms of their institutional functioning, the main provisions are the establishment of a "dialogue-based" communication as a consensus interaction [4].

The question of the functioning of libraries in the system of social and informational communications, their opportunities for improving the efficiency of activities is highlighted in the works of V.M. Gorovoy. The researcher considers libraries as social information bases and emphasizes the need to update the directions of work of library institutions to improve the quality of information resources, the development of the structure of information provision of libraries as a factor of the development of social information communications [3].

A. Sokolov considers the library of new information needs and user requests as a significant communication center. The scientist convincingly argues that the development of library functioning is under the influence of the overall development of social communications and information processing, which is due to the expansion of the spectrum of user needs [6].

An analysis of the approaches developed in library science points to the consistent communication of library services and the provision of the most up-to-date services to users, which in some way outlines the field of research. Meanwhile, the active use of the systematic, structuralfunctional, activity, institutional and new approach to librarianship - the sociosynergy in librarianship studies has defined the understanding of the library as an open, constantly evolving social-communicative system. Proof of the structural nature of the communication of this system and the creation of a unified structure that coordinates all communication flows in the library will open the possibility for a well-founded use of the notion of "communicative system" in relation to the library and the library social institute.

The development of social information communications in various spheres of information activity, including library, causes the formation of specific features of their functioning. These features are manifested in the specifics preparation of relevant information resources (specific and for widespread use), in the organization in accordance with the purpose of the channels of information transmission (e.g., printed editions of book-journal forms, dissemination of information through technical media capabilities, etc.), organization feedback mechanisms, evaluation of the effectiveness of social communications (direct contact with the customer, materials of sociological research, behavior analysis, user activity in the field of responses some kind of information support, etc.). Such specialization becomes more and more stable, differentiating, in turn, mainly in those who have already acquired certain specific features, directions.

The established point of view on the problem of communication in the library shows that the necessary transition from the description and analysis of parts that make up the communication process - user servicing, modern information and communication technologies, the system of external relations with authorities and other document and communication institutions to the structuring of all the main elements communications for further modeling of the integral structure of their interconnections. All levels of communication in the library, related to information processes, must be combined into a single structure. Simulation of a similar structure will make it possible to talk about the library as a communicative system.

The modern library acts as a certain communication structure, whose activity has a document-communication essence, connected with documentary funds, resources, 
information service system. The library serves as the basic social and communicative structure that concentrates the communication culture of society and provides communication processes using documents, information and knowledge.

The study of the library as a communication system involves consideration of its capabilities in the implementation of common tasks and the analysis of those areas that determine the specificity of the transmission of cultural and significant information. Being one of these communication channels, the library in the system of document and communication institutions of the society now claims to address the problems that have traditionally been addressed to other social-cultural institutions. The active transformation of library activity makes it possible to rethink its functions, to consider new possibilities of libraries, including in a network environment, to look for ways of realization of the mission. In this regard, it is especially important to distinguish the main components of the communication process in the library, to identify those areas of library activity in which it is implemented, to describe a set of tools that determine the specifics of communication processes. The structure of the communication system in the library will open the opportunity to highlight the general principles of developing a modern library as a socio-communicative system.

The analysis of the library's activities as a socialcommunicative system allows us to analyze its place in the historical and cultural continuum, to determine the specifics of its communication activities (in the broad sense, as the interaction of all components of the library institution), to define strategies for its development, role and place in the formation of the national information space. Today it can be argued that communication permeates all the main components of library and information activities, specifying the direction of their development. In this case, it is not simply recorded the existence of communication in various areas of library activity, but its structural affiliation as the most important component of the subsystem, which ensures its integrity and the possibility of development, is determined. The proof of this provision opens the door for further analysis of the library as a social-communicative system of the information society.

The communicative effectiveness of the library is undoubtedly achieved through the quality of library and information resources and services, and the comfort of access to them. In addition, the quality of performing social and communicative functions depends on the effectiveness of the library's contacts with other subjects of communication, their intensity, the degree of accessibility of communication tools, the level of competence of library staff, the inclusion of a library institution in the communication network, etc. This is emphasized by Ukrainian specialists [2].
The basis of the activity of any library is its document fund (printed, electronic, multimedia, virtual resources), whose social and informational significance corresponds to the needs of society. The means and channels for maintaining the communication environment of the library are related to technologies and processes, material and technical resources and personnel resources. The variability of the channels of information transmission is made possible by the communicative nature of the library as an open system that is developing and shaped in accordance with the interests and aspirations of society, as emphasized by librarians.

The main library resource has already acquired a digital character, and a possible reader has become distant. Then everything will depend on whether or not the library will be able to remain massively in demand on new spaces of the intersection of new types of carriers and new types of information consumers. Here for the library the door to the future - open or closed. And sometimes it threatens us directly. The task is to simultaneously continue to collect, accumulate traditional library resources and meet the information needs of traditional readers and maximally master the latest information resources and respond to the demands of the "digital" generation. Then libraries in the transition period will survive and confidently enter the information environment.

As it can be seen, libraries have solid advantages in competition with other information structures. Based on them, one needs to look for new forms and methods of building up library's competitive potential. The main field of competition between information structures for the influence on people is the area of interactions between the informer and information user. In our case, communication between the library and the reader. True, the traditional notion of "reader" impoverishes the characteristics of those who today turn to the library for services, and thereby inquires incomplete service.

Thus, the library of survival and development of the library lies in the plane of the library - reader / user / consumer / customer information services / non-regular employee. It is this communication system that is the future. All other library areas, although important, are necessary, but they must follow the generic functions of the library the dissemination of knowledge in society. Unfortunately, now there is a negative trend of separation of some library processes from service, tasks of practical feedback, their closure in themselves. This is observed when modernizing resources, processing documents, synthesizing information. And the weakening of the links between the internal structures of libraries is important. As a result the delay and incompleteness of the library when it comes to practice, reducing the credibility of the library in the information environment can be seen. Therefore, there is an urgent need to update and strengthen the course of the library to the reader, to increase its steady supporters.

\section{ЛІТЕРАТУРА}

1. Аронсон Э. Эпоха пропаганды: Механизмы убеждения повседневное использование и злоупотребление / Э. Аронсон, Э. Пратканис. - М.: Прайм-Еврознак, 2002. $384 \mathrm{c}$.

2. Вахнован В. Соціологічні дослідження як комунікаційний складник системи менеджменту якості бібліотечних послуг: автореф. дис. ..канд. наук із соціальних комунікацій:
27.00.03 / В. Вахнован / Харк. держ. акад. культури. - Х., 2011. - C. 4

3. Воскобойнікова-Гузєва О. Стратегії розвитку бібліотечноінформаційної сфери України: генезис, концепції, модернізація : монографія / О. Воскобойнікова-Гузєва; НАН України, Нац. б-ка України ім. В. І. Вернадського. - К., 2014. $-362 \mathrm{c}$. 
4. Горовий В. Національні інформаційні процеси в умовах глобалізації : монографія / В. Горовий; НАН України, Нац. б-ка України ім. В. І. Вернадського. - Київ, 2015. $332 \mathrm{c}$.

5. Горовий В. Особливості розвитку соціальних інформаційних баз сучасного українського суспільства / В. М. Горовий. - К.: НБУВ, 2005. - 300 с.

6. Матурана У. Биология познания / У. Матурана // Язык и интеллект. - М. : Прогресс, 1995. - С. 95-142.

7. Мізіна О. Комунікація у вербальних та невербальних засобах мовлення / О. Мізіна // Документно-інформаційні комунікації в умовах глобалізації: стан, проблеми і перс- пективи : матеріали II Всеукраїн. наук.-практ. Інтернетконф. (м. Полтава, 23 листопада 2016 р.) / редкол. : І. Г. Передерій, А. А. Соляник та ін. - Полтава : ПолтНТУ, 2016. - C. 43-47.

8. Соколов А. Общая теория социальной коммуникации: учеб. пособ. / А. В.Соколов. - СПб : Изд-во В. В.Михайлова, 2002. - 461 с.

9. Lasswell H. D. The structure and function of communication in society [Electronic resource] / D. H. Lasswell // Mode of access: http://profsw.files.wordpress.com/2009/03/12.pdf. Title from the screen.

\section{REFERENCES}

1. Aronson, E. Epoch of propaganda: Mechanisms of persuasion - everyday use and abuse. M.: Praim-Evroznak, 2002. 384 p.

2. Vaxnovan, V. Sociological research as a communication component of the quality management system of library services. Extended abstract of candidate's thesis. Kharkiv, 2011. p. 4.

3. Voskoboinikova-Huzieva, O. Strategy of development of the library and information sphere of Ukraine: genesis, concepts, modernization. K.: Akademperiodyka, 2014. 362 p.

4. Gorovyj, V. National information processes in the conditions of globalization. Kyiv: NBUV, 2015. 332 p.

5. Gorovyj, V. Features of the development of social information

bases of modern Ukrainian society. Kiev: NBUV, 2005. 300 p.

6. Maturana, U. Biology of knowledge // Language and intellect. M.: Progress, 1995. P. 95-142.

7. Mizina, O. Communication in verbal and non-verbal means of broadcasting. Document and Information Communication in the Conditions of Globalization: Status, Problems and Prospects: materials II of the All-Ukrainian scientific and practical Internet conference (Poltava, November 23, 2016). Poltava: PoltNTU, 2016. pp. 43-47.

8. Sokolov, A. The general theory of social communication. St. Petersburg: Izd-vo V. V. Mikhailova, 2002. 461 p.

\section{Библиотеки в системе социально-информационных коммуникаций}

\section{О. Н. Каращук}

Аннотация. В статье рассматриваются общие тенденции развития социальных информационных коммуникаций и роль библиотек как базовой социально-коммуникативной структуры, которая концентрирует коммуникационную культуру общества и обеспечивает коммуникационные процессы в обществе. Доказано, что библиотеки имеют солидные преимущества в конкуренции с другими информационными структурами благодаря доступу к огромным массивам информации в своих фондах. Проанализированы научные труды по представленной тематике.

Ключевые слова: сочиальные информационные коммуникации, вербальная и невербальная коммуникация, библиотечные ресурсы, библиотечные учреждения, библиотечный коммуникативный потенциал. 